DOI: https://doi.org/10.47405/mjssh.v5i9.476

\begin{tabular}{|c|c|}
\hline & Malaysian Journal of Social Sciences and Humanities (MJSSH) \\
\hline Malaysian Journal of & Volume 5, Issue 9, September 2020 \\
\hline (MJ-SSH) & e-ISSN : 2504-8562 \\
\hline & $\begin{array}{l}\text { Journal home page: } \\
\text { www.msocialsciences.com }\end{array}$ \\
\hline
\end{tabular}

\title{
Kesan Pembelajaran Berasaskan Permainan Digital Minecraft Terhadap Pencapaian Murid Tahun Lima dalam Pecahan
}

\author{
Rayner Bin Tangkui', Tan Choon Keong1 \\ 1Fakulti Psikologi dan Pendidikan, Universiti Malaysia Sabah (UMS) \\ Correspondence: Tan Choon Keong (cktums@gmail.com)
}

\begin{abstract}
Abstrak
Keupayaan untuk memahami dan menguasai konsep pecahan akan menyediakan asas yang kukuh untuk memahami konsep matematik yang lebih kompleks serta membantu dalam melakukan penyelesaian masalah yang melibatkan pecahan dalam kehidupan seharian. Namun demikian, dapatan pentaksiran antarabangsa Trends in Mathematics and Science Studies (TIMSS) dan Programme for International Student Assessment (PISA) menunjukkan bahawa pencapaian pecahan di kalangan murid di Malaysia adalah di tahap kurang memuaskan iaitu berada di bawah skor purata antarabangsa. Dengan mengambil kira perkembangan inovasi dan kecanggihan permainan digital masa kini, tujuan kajian ini adalah untuk mengkaji kesan pembelajaran berasaskan permainan digital menggunakan Minecraft terhadap peningkatan pencapaian murid dalam pecahan. Kuasi-eksperimen dengan reka bentuk ujian pra dan ujian pasca kumpulan rawatan dan kumpulan kawalan yang melibatkan 65 orang murid tahun lima dalam dua buah kelas sedia ada telah dijalankan. Melalui pensampelan kluster, sebuah kelas terpilih sebagai kumpulan rawatan manakala kelas yang satu lagi terpilih sebagai kumpulan kawalan. Kumpulan rawatan terdiri daripada 31orang murid yang didedahkan dengan kaedah pembelajaran berasaskan permainan digital menggunakan Minecraft manakala kumpulan kawalan terdiri daripada 34 orang murid yang didedahkan dengan kaedah konvensional. Data dianalisis menggunakan ujian-t dua kumpulan sampel tak bersandar bagi membandingkan min skor pencapaian ujian pasca bagi pecahan antara kumpulan rawatan dengan kumpulan kawalan. Terdapat perbezaan signifikan dalam min skor pencapaian antara kumpulan rawatan $(\mathrm{m}=51.096, \mathrm{sp}=17.242)$ dengan kumpulan kawalan $(\mathrm{m}=35.235, \mathrm{sp}=18.171)$. Hasil kajian ini akan lebih menggalakkan pelaksanaan pembelajaran berasaskan permainan digital menggunakan Minecraft dalam pengajaran matematik bagi meningkatkan pencapaian murid dalam pecahan.
\end{abstract}

Kata kunci: pembelajaran berasaskan permainan digital, minecraft, konsep pecahan, pencapaian

\section{The Effects of Digital Game-Based Learning Using Minecraft Towards Pupils' Achievement in Fraction}

\begin{abstract}
The ability to understand and master fraction concepts will provide a solid basis for understanding more complex mathematical concepts and assisting in solving problems involving fractions in everyday life. However, findings of the international assessments Trends in Mathematics and Science Studies (TIMSS) and Program for International Student Assessment (PISA) indicate that achievement of fractions among pupils in Malaysia is at a poor level, that is below the international average score. Taking into account the development of digital game innovation and sophistication, the purpose of this
\end{abstract}


study is to investigate the effect of digital game-based learning using Minecraft on pupils' achievement in fractions. A quasi-experiment with a pre-test and post-test control group was conducted involving 65 year five pupils in two intact classes. Through cluster sampling, one class was selected as the treatment group while the other class was selected as the control group. The treatment group consisted of 31 pupils which were exposed to digital game-based learning methods using Minecraft while the control group consisted of 34 pupils which were exposed to conventional methods. Data was analysed using independent sample t-test to compare the post-test mean achievement scores for fraction between the treatment group and the control group. There was significant difference in mean achievement scores between the treatment group $(\mathrm{m}=51.096, \mathrm{sd}=17.242)$ and the control group $(\mathrm{m}=35.235, \mathrm{sd}=$ 18.171). The findings from this study would further encourage the use of digital game-based learning using Minecraft in the teaching of mathematics to increase pupils' achievement in fractions.

Keywords: digital game-based learning, minecraft, fraction concept, achievement

\section{Pengenalan}

Pecahan adalah kompleks namun merupakan konsep yang penting dalam matematik. Pemahaman konsep pecahan adalah penting bukan hanya untuk menyediakan asas yang kukuh untuk membentuk dan mengembangkan idea matematik (Zakiah et. al., 2013) tetapi juga membantu dalam penguasaan konsep matematik lain yang lebih kompleks seperti konsep algebra (Booth et. al., 2014). Di samping itu, pengetahuan konsep pecahan yang baik akan membantu dalam penyelesaian masalah yang dihadapi dalam kehidupan seharian khususnya yang melibatkan pengiraan dan pengukuran seperti peratus, nisbah, kadar serta perpuluhan (Abdul Halim et. al., 2015; Booth \& Newton, 2012; Ndalichako, 2013; Wijaya, 2017). Di Malaysia, berdasarkan sukatan kurikulum Matematik dalam Kurikulum Standard Sekolah Rendah (KSSR), topik pecahan telah mula diperkenalkan kepada murid sejak dari Tahun Satu lagi (Kementerian Pendidikan Malaysia, 2015). Pecahan merupakan salah satu tajuk dalam bidang Nombor dan Operasi yang diajar selepas topik nombor bulat.

Walapun topik pecahan telah didedahkan kepada murid sekolah rendah sejak dari Tahun Satu, kebanyakan murid Malaysia masih mengalami kesukaran dalam mempelajari dan menguasai topik tersebut. Kesukaran yang dihadapi dalam mempelajari pecahan telah menyebabkan murid Malaysia memperoleh pencapaian yang kurang memuaskan dalam pecahan (Abdul Halim et. al., 2015). Laporan pentaksiran antarabangsa Trends in Mathematics and Science Study (TIMSS) serta Programme for International Student Assessment (PISA) menunjukkan bahawa purata skor pencapaian pelajar Malaysia dalam Matematik adalah di bawah skor purata antarbangsa. Pecahan merupakan tajuk yang diuji dalam kandungan domain Nombor. Pelajar Malaysia memperoleh purata skor 465 dalam TIMSS 2015. Purata skor ini berada di bawah skor purata antarabangsa iaitu 500. Berdasarkan skor ini, Malaysia berada di kedudukan Penandaarasaan Antarabangsa Rendah (Mullis et. al., 2016). Dalam PISA 2012, pelajar Malaysia memperoleh skor literasi Matematik 421, namun skor ini masih berada di bawah purata skor antarbangsa iaitu 548 (Abdul Halim et. al., 2015; OECD, 2013).

Berdasarkan kandungan KSSR bagi Matematik, pecahan merupakan topik yang diajar setelah muridmurid didedahkan dengan nombor bulat dan operasi asas tambah, tolak, darab dan bahagi serta operasi bergabung dalam bidang pembelajaran Nombor dan Operasi (Kementerian Pendidikan Malaysia, 2014; Noorbaizura \& Leong, 2013). Pendedahan terhadap nombor bulat dan operasi asas tambah dan tolak telah menyebabkan murid-murid cenderung melakukan penyelesaian operasi penambahan dan penolakan pecahan berpandukan pengetahuan dan kemahiran nombor bulat iaitu dengan menambah atau menolak terus pengangka dengan pengangka dan penyebut dengan penyebut (Dhlamini \& Kibirige, 2014; Li, 2014; Loong, 2014; Ndalichako, 2013). Dapatan ini jelas menunjukkan bahawa murid mempunyai pengetahuan dan pemahaman konsep pecahan yang belum kukuh atau mendalam (Almeda et. al., 2013; Azurah \& Effandi, 2015; Bottge et. al., 2014; Zakiah et. al., 2013). Semasa diperkenalkan dengan topik pecahan, kebanyakan murid mengalami miskonsepsi yang menyebabkan mereka menghadapi kesukaran untuk memahami dan menguasai topik tersebut dengan baik. Pengaruh nombor bulat merupakan salah satu faktor yang menyumbang kepada miskonsepsi tersebut. 
Miskonsepsi nombor bulat adalah tanggapan murid bahawa konsep nombor bulat boleh diaplikasikan ke atas pecahan kerana konsep nombor bulat dan konsep pecahan adalah sama (Lamon, 2008; Siegler \& Pyke, 2013). Van de Walle, Karp \& Bay-Williams (2019) menjelaskan bahawa murid cenderung mengeneralisasikan pengetahuan yang dipelajari daripada topik nombor bulat ke topik pecahan, yang mempunyai struktur yang berbeza daripada nombor bulat. Alibali dan Sidney (2015) merujuk miskonsepsi ini sebagai Natural Number Bias manakala menurut Ni dan Zhou (2005), miskonsepsi ini dikenali sebagai Whole Number Bias. Kewujudan miskonsepsi ini menjejaskan pemahaman murid terhadap pecahan disebabkan murid menganggap bahawa pengangka dan penyebut adalah dua nombor bulat yang berasingan dan bukannya dua nombor yang mempunyai hubungan antara satu dengan yang lain (DeWolf \& Vosniadou, 2015) dan memberi kesan terhadap keupayaan murid melakukan penyelesaian masalah pecahan sehingga menjejaskan pencapaian murid.

Bagi mengukuhkan pemahaman dan penguasaan konsep pecahan sekali gus meningkatkan pencapaian murid dalam pecahan, pembelajaran berasaskan permainan digital dilihat sebagai pendekatan yang sesuai dan perlu diaplikasi bagi mencapai matlamat yang dinyatakan di atas khususnya melalui penggunaan Minecraft.

\section{Tinjauan Literatur}

\section{Pembelajaran Berasaskan Permainan Digital}

Tidak dapat dinafikan bahawa permainan digital mendapat permintaan dan sambutan yang tinggi tahun demi tahun sehingga menjadikan industri permainan digital sebagai industri yang bernilai berbilion dolar (Malaysian Investment Development Industry, 2020). Entertainment Software Association (2019) menganggarkan bahawa nilai jualan permainan digital pada tahun 2018 bagi pasaran di Amerika Syarikat adalah melebihi 43.3 bilion USD. Sebanyak 165 juta atau 65\% penduduk dewasa di Amerika Syarikat yang merangkumi pelbagai peringkat umur, kaum dan jantina memainkan permainan digital. Purata umur individu yang bermain permainan digital adalah 33 tahun dengan purata masa yang dihabiskan untuk bermain permainan digital adalah 8.3 jam seminggu. Wijman (2020) menyatakan bahawa menjelang tahun 2020, pasaran permainan digital global akan menjana pendapatan sebanyak 159.3 bilion USD. Statistik ini jelas menunjukkan bahawa permainan digital sememangnya mendapat permintaan dan sambutan yang tinggi dan ini berlaku disebabkan permainan digital menawarkan sesuatu yang sangat dicari oleh setiap individu iaitu hiburan dan kepuasan (Ritterfield \& Weber, 2006). Elemen hiburan dan kepuasan yang ditawarkan permainan digital telah menyumbang kepada peningkatan permintaan yang memberangsangkan terhadap permainan digital disebabkan keupayaan permainan digital untuk menarik perhatian, menggalak keterlibatan (encourage engagement) serta bersifat immersive, iaitu berupaya mencetus penghayatan yang tinggi kepada pemainnya sehingga permainan digital tersebut dimainkan selama berjam-jam (Kirriemuir \& McFarlene, 2004).

Melihat kepada keupayaan permainan digital untuk mencetus permintaan yang tinggi di kalangan pelbagai golongan individu tanpa mengira jantina (Burke, 2000), latar belakang etnik (Bickham et.al., 2003) serta peringkat umur (IDSA, 2003), telah wujud usaha di kalangan golongan pendidik untuk mengintegrasi permainan digital ke dalam persekitaran pendidikan khususnya dalam pelaksanaan PdPc dengan harapan permainan digital dapat menyokong dan menggalakkan lagi keterlibatan aktif murid dalam pembelajaran agar objektif pembelajaran yang disasarkan dapat dicapai. Pengintegrasian permainan digital ke dalam persekitaran pembelajaran telah menghasilkan kaedah pembelajaran yang dikenali sebagai pembelajaran berasaskan permainan digital.

Pembelajaran berasaskan permainan digital telah mendapat perhatian dalam persekitaran pendidikan semenjak 20 tahun yang lepas (Aishah et. al., 2012; All et. al., 2014; Boyle et. al., 2016; Li \& Tsai, 2013; McLaren et. al., 2017; Westera, 2014). Tidak terdapat definisi yang tepat untuk menjelaskan mengenai pembelajaran berasaskan permainan digital (Huizenga, 2017; Wong \& Kamisah, 2018), namun pembelajaran berasaskan permainan digital lazimnya di definisi berdasarkan beberapa ciri umum. Menurut All, Castellar dan Van Looy (2017), pembelajaran berasaskan permainan digital 
adalah penggunaan permainan digital untuk tujuan pendidikan yang mengandungi kedua-dua elemen hiburan dan pendidikan. Al-Azawi, Al-Faliti dan Al-Blushi (2016) mendefinisikan pembelajaran berasaskan permainan digital sebagai integrasi permainan digital dalam PdPc yang bertujuan untuk meningkatkan pengalaman pembelajaran. Sebagai sebuah kaedah pembelajaran yang mempromosi pendekatan belajar sambil bermain (Hwang et. al., 2015; Yang, 2015), pembelajaran berasaskan permainan digital diaplikasi bagi menjadikan suasana pembelajaran lebih menyeronokkan berbanding kaedah konvensional (Wang et. al., 2011). Menurut Prensky (2001), pembelajaran berasaskan permainan digital adalah pendekatan pembelajaran yang berasaskan permainan digital, di mana penggunaannya adalah bagi mencapai objektif pembelajaran (Wiggins, 2016). Walaupun terdapat pelbagai definisi mengenai pembelajaran berasaskan permainan digital, kaedah PdPc ini dapat dikenal pasti melalui beberapa ciri tertentu berbanding kaedah PdPc lain. Kaedah PdPc ini melibatkan penggabungan ciri permainan (game features) dengan kandungan pengajaran. Melalui penggabungan ini, murid mempunyai bahan bantu belajar (learning aids) yang berperanan menyokong murid dalam pembelajaran. Bawa, Watson dan Watson (2018) turut menambah bahawa ciri-ciri pembelajaran berasaskan permainan digital adalah mempunyai antara muka bergambar (pictorial interface) dan wujudnya cabaran yang akan menggalakkan murid untuk terlibat secara aktif dalam pembelajaran apabila murid melaksanakan penyelesaian ke atas cabaran tersebut.

Kebanyakan kajian yang dijalankan berkenaan pembelajaran berasaskan permainan digital telah melibatkan pelbagai pemboleh ubah seperti keterlibatan (Annetta et. al., 2010), motivasi (Iacovides et. al., 2011), prestasi pembelajaran (Chen et. al., 2012), kemahiran kognitif (Kim et. al., 2009), kreativiti (Behnamnia et. al., 2020) dan pencapaian akademik (Chen, 2017; Siew et. al., 2016; Yeh et. al., 2017) serta melibatkan pelbagai subjek seperti Bahasa Inggeris (Yeh, et. al., 2017), Geografi (Khairuddin et. al., 2017), Fizik (Kao et. al., 2017), Matematik (Ku et. al., 2014) dan Sains (Hwang et. al, 2014). Spesifik bagi pencapaian akademik, walaupun terdapat beberapa kajian yang telah dijalankan, dapatan empirikal berkenaan kesan pembelajaran berasaskan permainan digital terhadap peningkatan pencapaian akademik murid masih perlu diperbanyakkan lagi (All et. al., 2017). Pembelajaran berasaskan permainan digital dilihat mempunyai potensi untuk meningkatkan pencapaian akademik disebabkan kaedah pembelajaran ini berupaya menyediakan pengalaman pembelajaran yang menarik, mencabar keupayaan, menggalak keterlibatan serta mencetus motivasi yang akan meningkatkan minat murid terhadap subjek yang disampaikan guru dan seterusnya meningkatkan prestasi akademik (Chang et. al., 2012; Meluso et. al., 2012; Siew et. al., 2016).

\section{Permainan Digital Minecraft}

Minecraft merupakan sebuah permainan digital 'sandbox' yang popular di mana lebih 100 juta unit telah terjual di seluruh dunia. Dunia maya yang dicipta dalam Minecraft adalah dunia blok 3D di mana pemain berupaya untuk meneroka dan membina secara bebas. Sebagai sebuah permainan digital 'dunia'terbuka', pemain melakukan penerokaan dan penjelajahan dalam dunia maya Minecraft tanpa adanya pengakhiran yang jelas atau sasaran yang perlu dicapai (Donellan, 2019). Pemain menggunakan pelbagai jenis batu atau blok, yang berbentuk kubus dengan enam muka unit persegi, untuk membina pelbagai jenis objek serta struktur. Minecraft telah digunakan sebagai alat bantu mengajar untuk pelbagai topik dan subjek di seluruh dunia (Minecraft Teachers, 2015; Short, 2012).

Golongan pendidik telah mengenal pasti beberapa manfaat yang dapat diperolehi apabila Minecraft digunakan sebagai alat pengajaran dan manfaat ini merangkumi pelbagai bidang dan subjek seperti matematik (Bos et. al., 2014). Sebagai contoh, Minecraft membolehkan seseorang murid atau pemain untuk mengumpul (collecting), memecah (breaking), membina semula (reconstructing), mengalih (removing) dan meletak (placing) objek berbentuk blok 3D secara rawak dalam dunia maya tersebut, di mana perlakuan ini membolehkan pemain membentuk sebarang objek atau struktur mengikut daya imaginasi pemain (Bos et. al., 2014; Ekaputra et. al., 2013; Kim \& Park, 2018; Lane et. al., 2017; Mojang, 2015a; Nebel et. al., 2016) yang berupaya untuk bertindak sebagai stimuli atau rangsangan untuk pelbagai aktiviti atau projek pembelajaran dan dalam masa yang sama adalah menghibur dan menyeronokkan. 


\section{Pembelajaran Pecahan Menggunakan Minecraft}

Kebanyakkan murid menghadapi kesukaran untuk memahami konsep asas pecahan terutama konsep hubungan pengangka dengan penyebut serta konsep pecahan setara (Rodrigues et. al., 2017; Siegler \& Pyke, 2013). Menurut Stafylidou dan Vosniadou (2004), murid melihat pecahan sebagai sepasang nombor yang mewakili kuantiti tertentu tanpa memahami bahawa wujudnya hubungan antara keduadua kuantiti tersebut. Miskonsepsi terhadap konsep pecahan yang abstrak ini telah menyebabkan murid tidak mempunyai pemahaman dan pengetahuan konseptual pecahan yang baik (Simon et. al., 2018; Zakiah et. al., 2013). Penggunaan Minecraft dilihat berpotensi dalam mengukuhkan pemahaman dan pengetahuan konseptual pecahan disebabkan Minecraft membolehkan aktiviti manipulasi secara hands-on dilakukan ke atas blok 3D dalam dunia maya Minecraft terutama semasa melakukan penyelesaian masalah pecahan. Blok 3D dalam dunia Minecraft dapat disusun bagi menghasilkan struktur atau objek yang mewakili pecahan yang dikenali sebagai model pecahan (fraction model). Model pecahan ini membolehkan murid untuk memvisualisasi nilai pecahan dengan lebih mudah serta jelas dan seterusnya membantu murid untuk memahami konsep pecahan dengan lebih baik. Sebagai contoh, dalam rajah 1, dua blok 3D berwarna merah yang diletakkan di atas blok 3D lutsinar akan membentuk model pecahan dengan nilai 'dua per tiga'. Interpretasi susunan blok 3D tersebut adalah susunan tiga blok 3D menunjukkan nilai penyebut tiga manakala dua blok 3D bewarna merah menunjukkan nilai pengangka dua.

Melalui manipulasi hands-on ke atas blok-blok 3D tersebut, yang dikenali juga sebagai manipulatif iaitu bahan atau objek yang dimanipulasi, aktiviti berkaitan operasi asas seperti menambah, menolak dan mendarab pecahan dapat dilakukan dalam Minecraft. Pelaksanaan aktiviti hands-on ini akan membantu mewujudkan hubungan antara aktiviti berkenaan dengan konsep pecahan yang abstrak kerana dengan berinteraksi serta melakukan aktiviti secara hands-on, kemahiran matematik murid akan dapat dipertingkat dan ini sekali gus membantu murid untuk memahami konsep matematik yang abstrak kerana murid dapat memvisualisasikan konsep tersebut dengan baik dalam minda (Holmes, 2013; Kontaş, 2016). Manipulasi yang dilakukan ke atas bahan manipulatif sama ada dalam bentuk objek konkrit mahupun bentuk maya akan membantu memperkukuh pemahaman konsep matematik (Hartshorn \& Boren, 1990). Murid juga akan membina pengetahuan yang semakin kompleks melalui penglibatan aktif dengan bahan manipulatif (Bruner, 1977; Dienes, 1973; Piaget, 1965). Rajah 2 menunjukkan contoh aktiviti melibatkan pecahan yang dapat disediakan guru di dalam Minecraft untuk diselesaikan oleh murid.

Rajah 1: Susunan blok yang membentuk nilai pecahan 'dua per tiga'

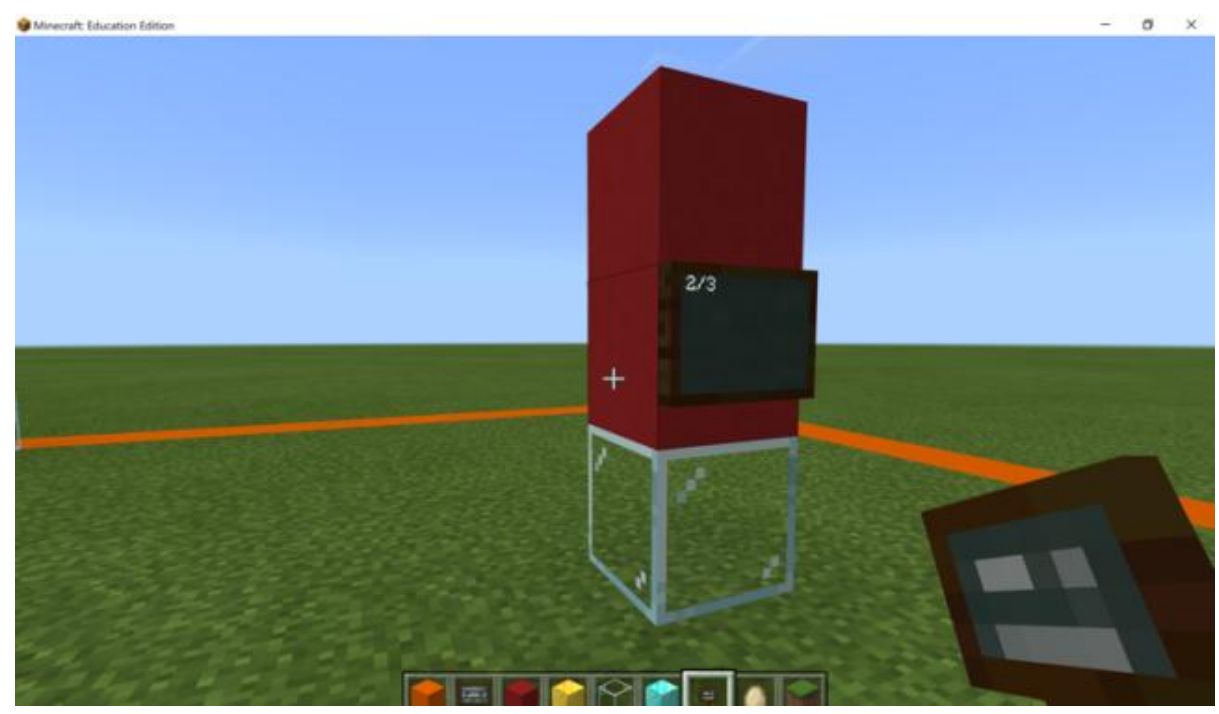




\section{Rajah 2: Aktiviti Penyelesaian Masalah Menggunakan Model} Pecahan Melalui Manipulasi Blok 3D

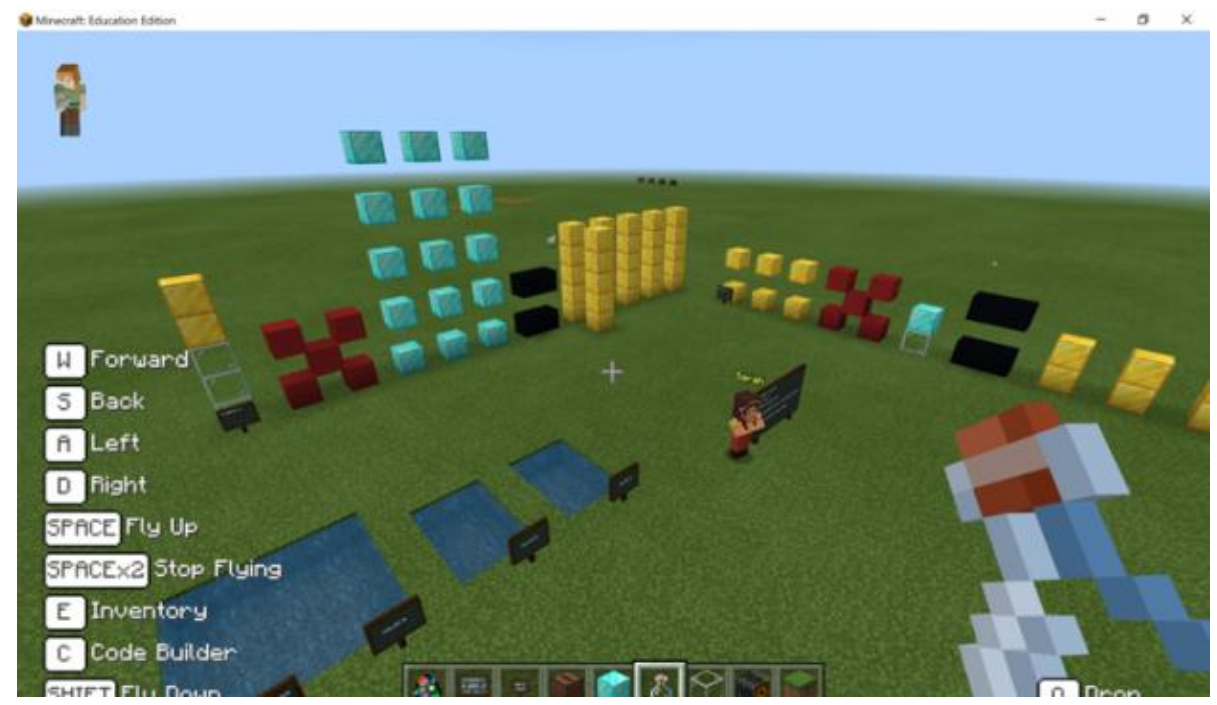

Dengan itu, kajian ini bertujuan untuk mengenal pasti kesan pembelajaran berasaskan permainan digital menggunakan Minecraft dalam meningkatkan pencapaian murid Tahun Lima dalam pecahan. Kajian ini dijalankan di sebuah sekolah rendah di Sabah dengan hipotesis kajian seperti berikut :

i. Tidak terdapat perbezaan yang signifikan antara skor min markah pencapaian ujian pra dengan skor min markah pencapaian ujian pasca bagi topik pecahan dalam kumpulan kawalan.

ii. Tidak terdapat perbezaan yang signifikan antara skor min markah pencapaian ujian pra dengan skor min markah pencapaian ujian pasca bagi topik pecahan dalam kumpulan rawatan.

iii. Tidak terdapat perbezaan yang signifikan dalam skor min markah pencapaian ujian pasca antara kumpulan kawalan dengan kumpulan rawatan.

\section{Metodologi}

\section{Reka Bentuk Kajian}

Kajian ini menggunakan reka bentuk kuasi-eksperimen jenis ujian pra dan ujian pasca kumpulan kawalan dan kumpulan rawatan. Pemboleh ubah tidak bersandar adalah kaedah pengajaran manakala pemboleh ubah bersandar adalah pencapaian murid dalam topik pecahan. Kumpulan rawatan didedahkan dengan kaedah pembelajaran berasaskan permainan digital manakala kumpulan kawalan didedahkan dengan kaedah pengajaran konvensional. Sesi pengajaran dan pemudahcaraan (PdPc) dilaksanakan selama tujuh minggu berpandukan jadual rancangan pengajaran guru bagi topik pecahan yang melibatkan subtopik penambahan pecahan, penolakan pecahan, penambahan dan penolakan pecahan serta konsep 'daripada' dalam pecahan setelah ujian pra ditadbir kepada kedua-dua kumpulan. Ujian pasca ditadbir pada minggu ke lapan setelah sesi PdPc selesai dilaksanakan ke atas kedua-dua kumpulan. Jadual 1 menunjukkan reka bentuk kajian ini.

Jadual 1 : Reka Bentuk Kajian Kuasi-Eksperimen Ujian Pra dan Ujian Pasca Kumpulan Kawalan dan Kumpulan Rawatan

\begin{tabular}{cccc}
\hline Kumpulan & Ujian Pra & Kaedah Pengajaran & Ujian Pasca \\
\hline Kawalan & $\mathrm{O}_{1}$ & $\mathrm{X}_{1}$ & $\mathrm{O}_{2}$ \\
Rawatan & $\mathrm{O}_{1}$ & $\mathrm{X}_{2}$ & $\mathrm{O}_{2}$ \\
\hline
\end{tabular}


Petunjuk:

$\mathrm{O}_{1}$ : Ukuran pencapaian skor (Ujian pra)

$\mathrm{O}_{2}$ : Ukuran pencapaian skor (Ujian pasca)

$\mathrm{X}_{1}: \operatorname{PdPc}$ (Kaedah konvensional)

$\mathrm{X}_{2}: \mathrm{PdPc}$ (Kaedah pembelajaran berasaskan permainan digital menggunakan Minecraft)

Langkah-langkah telah diambil oleh pengkaji untuk memastikan eksperimen yang dijalankan mempunyai kesahan dalaman yang tinggi. Kesahan dalaman merujuk kepada keadaan apabila pemboleh ubah luaran yang tidak berkaitan dengan kajian telah dikawal atau disingkir (Gay \& Airasian, 2011). Eksperimen dengan kesahan dalaman yang tinggi telah mengurangkan potensi pengaruh pemboleh ubah luaran sehingga ke tahap di mana pemboleh ubah tidak bersandar merupakan pemboleh ubah yang paling mungkin menyebabkan berlakunya perubahan pada pemboleh ubah bersandar. Pemboleh ubah luaran yang menjadi ancaman kepada kesahan dalaman telah dikenal pasti dan dikawal dan pemboleh ubah luaran tersebut merangkumi i) sejarah, ii) kesan penyelidik iii) kematangan, iv) kesan sampel kajian, v) pemilihan sampel kajian, vi) instrumentasi, vii) pengujian dan viii) situasi seperti yang dicadangkan oleh Creswell (2014).

\section{Sampel Kajian}

Sampel kajian terdiri daripada 65 orang murid Tahun Lima dalam dua buah kelas sedia ada di sebuah sekolah rendah di daerah Kuala Penyu, Sabah. Melalui pensampelan kluster, kelas yang mengandungi 34 orang murid terpilih sebagai kumpulan kawalan manakala kelas yang mengandungi 31 orang murid terpilih sebagai kumpulan rawatan. Kumpulan rawatan didedahkan dengan kaedah pembelajaran berasaskan permainan digital menggunakan Minecraft manakala kumpulan kawalan didedahkan dengan kaedah konvensional. Sesi PdPc bagi kedua-dua kumpulan dikendalikan oleh seorang guru matematik dari sekolah rendah berkenaan.

\section{Instrumen Kajian}

Instrumen kajian bagi kajian ini adalah terdiri daripada ujian pra dan ujian pasca. Soalan atau item yang dibangunkan dalam kedua-dua instrumen kajian tersebut adalah berdasarkan rujukan terhadap sukatan KSSR Matematik Tahun Lima dan buku teks Matematik Tahun Lima yang merangkumi subtopik penambahan pecahan, penolakan pecahan, penambahan dan penolakan pecahan serta konsep 'daripada' dalam pecahan. Kedua-dua instrumen kajian tersebut mengandungi 15 item subjektif yang menguji keupayaan penyelesaian masalah murid bagi topik pecahan. Item-item tersebut dibina berdasarkan rujukan terhadap Dokumen Standard Kurikulum dan Pentaksiran (DSKP) Matematik Tahun Lima serta buku teks Matematik Tahun Lima. Kedua-dua instrumen kajian menggunakan item yang sama cuma dibezakan dari segi susunan urutan nombor item yang disoal. Ujian pra ditadbir kepada semua sampel kajian sebelum didedahkan dengan rawatan dan bertujuan untuk menilai pengetahuan sedia ada sampel kajian dalam topik pecahan. Ujian pasca ditadbir untuk mengukur kesan rawatan iaitu sama ada berlakunya peningkatan pencapaian. Pengkaji telah merujuk empat orang pakar dalam bidang Matematik untuk tujuan semakan ke atas kedua-dua instrumen kajian berkenaan. Semakan pakar adalah perlu untuk memastikan ketepatan dan kejelasan isi kandungan ujian yang akan ditadbir (Kline, 2005).

\section{Prosedur Kajian}

Pelaksanaan kajian ini mengambil masa sembilan minggu, di mana tempoh masa pelaksanaan sesi PdPc adalah selama tujuh minggu. Sebelum kajian dilaksanakan, latihan berkenaan prosedur pentadbiran ujian pra, ujian pasca serta cara dan teknik menggunakan Minecraft dalam kaedah pembelajaran berasaskan permainan digital telah dijalankan terlebih dulu sebanyak lima sesi selama dua minggu bersama guru Matematik yang akan mengendalikan sesi PdPc menggunakan Minecraft tersebut. Setelah selesai menjalani latihan, minggu pertama pelaksanaan kajian dimulakan dengan pentadbiran ujian pra kepada kedua-dua kumpulan kawalan dan kumpulan rawatan. Tujuan pentadbiran ujian pra adalah untuk menilai pengetahuan sedia ada murid berkenaan topik pecahan. Ini 
DOI: https://doi.org/10.47405/mjssh.v5i9.476

disusuli dengan pelaksanaan eksperimen iaitu sesi PdPc selama tujuh minggu iaitu dari minggu kedua sehingga minggu kelapan dengan murid dalam kumpulan rawatan didedahkan dengan kaedah pembelajaran berasaskan permainan digital menggunakan Minecraft dan murid dalam kumpulan kawalan didedahkan dengan kaedah konvensional. Dalam kumpulan rawatan, sesi PdPc melibatkan pelaksanaan aktiviti pecahan di dalam beberapa dunia Minecraft (Minecraft world) yang telah dibangunkan khusus untuk kemahiran penyelesaian masalah pecahan tertentu. Jadual 2 menunjukkan senarai dunia Minecraft yang mengandungi aktiviti penyelesaian masalah pecahan tersebut. Ujian pasca ditadbir kepada kedua-dua kumpulan pada minggu kesembilan setelah sesi PdPc selesai dijalankan.

Jadual 2 : Senarai Nama Dunia Minecraft dan Penerangan Aktiviti Berkaitan Kemahiran Pecahan

\begin{tabular}{ll}
\hline Nama Dunia Minecraft & Penerangan \\
\hline Pengenalan model pecahan & $\begin{array}{l}\text { Dunia Minecraft di mana nilai pecahan ditunjukkan } \\
\text { dalam bentuk model melalui penyusunan blok 3D }\end{array}$ \\
& Dunia Minecraft yang memperkenalkan pecahan wajar. \\
Contoh pecahan wajar dibentuk melalui penyusunan \\
Pecahan wajar & $\begin{array}{l}\text { Dunia Minecraft yang memperkenalkan pecahan tak } \\
\text { wajar. Contoh pecahan tak wajar dibentuk melalui }\end{array}$ \\
Pecahan tak wajar & Denyusunan blok 3D \\
& nunia Minecraft yang memperkenalkan pecahan \\
Pecahan nombor bercampur & dibentuk melalui penyusunan blok 3D. \\
& Dunia Minecraft yang memperkenalkan pecahan setara. \\
Pecahan setara & Contoh pecahan setara dibentuk melalui penyusunan \\
blok 3D & Dunia Minecraft di mana guru menunjukkan bagaimana \\
melakukan penambahan pecahan. Penambahan pecahan & melibatkan nilai pecahan sama penyebut, pecahan beza \\
Demonstrasi penambahan & penyebut serta pecahan nombor bercampur.
\end{tabular}

Dunia Minecraft di mana guru menunjukkan bagaimana

Demonstrasi penolakan pecahan melakukan penolakan pecahan. Penolakan pecahan melibatkan nilai pecahan sama penyebut, pecahan beza penyebut serta pecahan nombor bercampur.

Dunia Minecraft di mana guru menunjukkan bagaimana Demonstrasi pendaraban pecahan melakukan pendaraban pecahan. Pendaraban pecahan melibatkan nilai pecahan sama penyebut, pecahan beza penyebut serta pecahan nombor bercampur.

Dunia Minecraft di mana murid melakukan aktiviti

Latihan menambah pecahan penambahan pecahan dengan memanipulasi blok atau kiub yang terdapat dalam dunia Minecraft tersebut.

Dunia Minecraft di mana murid melakukan aktiviti Latihan menolak pecahan penolakan pecahan dengan memanipulasi blok atau kiub yang terdapat dalam dunia Minecraft tersebut.

Dunia Minecraft di mana murid melakukan aktiviti Latihan mendarab pecahan pendaraban pecahan dengan memanipulasi blok atau kiub yang terdapat dalam dunia Minecraft tersebut. 


\section{Dapatan Kajian}

Analisis data bagi kajian ini menggunakan teknik statistik inferensi. Statistik inferensi adalah teknik statistik yang digunakan untuk menganalisis data yang diperoleh daripada pengukuran yang dilakukan terhadap sampel kajian dengan tujuan untuk membandingkan antara kumpulan rawatan dan kumpulan kawalan dan melakukan generalisasi terhadap populasi sampel yang lebih besar (William et. al., 2017). Statistik inferensi dalam kajian ini melibatkan ujian-t sampel bersandar dan ujian-t dua kumpulan tak bersandar. Sebelum analisis statistik dilaksanakan, ujian kenormalan dilakukan terlebih dahulu bagi menentukan sama ada data yang diperoleh daripada sampel kajian adalah tertabur secara normal atau tidak. Data yang diperoleh daripada sampel kajian perlu tertabur secara normal atau menghampiri taburan normal bagi memastikan data tersebut mempunyai ciri-ciri populasi,seperti mana data dalam populasi adalah tertabur secara normal (Nor Aishah et. al., 2011). Analisis kenormalan data bagi ujian pra dan ujian pasca kumpulan kawalan telah dilaksanakan menggunakan perisian SPSS dan dapatan analisis tersebut ditunjukkan dalam jadual 3 dan jadual 4 manakala analisis kenormalan data bagi ujian pra dan ujian pasca kumpulan rawatan ditunjukkan dalam jadual 5 dan jadual 6 . Ujian Shapiro-Wilk digunakan untuk menguji kenormalan data disebabkan ujian Shapiro-Wilk merupakan ujian normaliti yang terbaik (Nor Aishah et. al., 2011).

Jadual 3: Analisis Kenormalan Data bagi Ujian Pra Kumpulan Kawalan

\begin{tabular}{cccc}
\hline Kategori Markah & Statistik & df & Sig. \\
\hline Markah Ujian Pra & .947 & 34 & .099 \\
\hline
\end{tabular}

Jadual 4: Analisis Kenormalan Data bagi Ujian Pasca Kumpulan Kawalan

\begin{tabular}{cccc}
\hline Kategori Markah & Statistik & df & Sig. \\
\hline Markah Ujian Pasca & .942 & 34 & .071 \\
\hline
\end{tabular}

Jadual 5: Analisis Kenormalan Data bagi Ujian Pra Kumpulan Rawatan

\begin{tabular}{cccc}
\hline Kategori Markah & Statistik & df & Sig. \\
\hline Markah Ujian Pra & .941 & 31 & .087 \\
\hline
\end{tabular}

Jadual 6: Analisis Kenormalan Data bagi Ujian Pasca Kumpulan Rawatan

\begin{tabular}{cccc}
\hline Kategori Markah & Statistik & df & Sig. \\
\hline Markah Ujian Pasca & .935 & 31 & .061 \\
\hline
\end{tabular}

Nilai Sig. bagi keempat-empat ujian Shapiro-Wilk adalah lebih besar daripada nilai signifikan .05 dan ini menunjukkan bahawa data bagi ujian pra kumpulan kawalan, data bagi ujian pasca kumpulan kawalan, data bagi ujian pra kumpulan rawatan dan data bagi ujian pasca kumpulan rawatan adalah tertabur secara normal.

\section{Hipotesis $H_{0} 1$ : Tidak terdapat perbezaan yang signifikan antara skor min markah pencapaian ujian pra dengan skor min markah pencapaian ujian pasca bagi topik pecahan dalam kumpulan kawalan}

Ujian-t sampel bersandar kumpulan kawalan telah dijalankan untuk mengenal pasti perbezaan min markah pencapaian ujian pra dengan min markah pencapaian ujian pasca dalam kumpulan kawalan. Berdasarkan jadual 7, tidak terdapat perbezaan yang signifikan antara min markah pencapaian ujian 
pra $(\min =6.029)$ dengan min markah pencapaian ujian pasca $(\min =6.205)$ bagi topik pecahan dalam kumpulan kawalan dengan $\mathrm{t}=-1.358, \mathrm{p}>.05$. Ini bermakna hipotesis nol gagal ditolak.

Jadual 7 : Perbandingan Min Markah Pencapaian Ujian Pra dan

Ujian Pasca Kumpulan Kawalan

\begin{tabular}{lccccccc} 
& N & Min & $\begin{array}{c}\text { Sisihan } \\
\text { Piawai }\end{array}$ & $\begin{array}{c}\text { Perbezaan } \\
\text { Min }\end{array}$ & Nilai-t & df & p \\
\hline Markah Ujian Pra & & 6.029 & 2.757 & & & & \\
$\begin{array}{l}\text { Markah Ujian } \\
\text { pasca }\end{array}$ & 34 & 6.205 & 2.793 & -.176 & -1.358 & 33 & .184 \\
\hline * signifikan pada $p>.05$ & & & & & & & \\
\hline
\end{tabular}

\section{Hipotesis $\mathrm{H}_{0} 2$ : Tidak terdapat perbezaan yang signifikan antara skor min markah pencapaian ujian pra dengan skor min markah pencapaian ujian pasca bagi topik pecahan dalam kumpulan rawatan}

Ujian-t sampel bersandar kumpulan rawatan telah dijalankan untuk mengenal pasti perbezaan min markah pencapaian ujian pra dan ujian pasca dalam kumpulan rawatan. Berdasarkan jadual 8 , terdapat perbezaan yang signifikan antara min markah pencapaian ujian pra $(\min =6.935)$ dengan min markah pencapaian ujian pasca $(\mathrm{min}=8.806)$ bagi topik pecahan dalam kumpulan rawatan dengan $\mathrm{t}=-1.870$, $\mathrm{p}>$.05. Ini bermakna hipotesis nol ditolak.

Jadual 8: Perbandingan Min Markah Pencapaian Ujian Pra dan Ujian Pasca Kumpulan Rawatan

\begin{tabular}{|c|c|c|c|c|c|c|c|}
\hline & $\mathbf{N}$ & Min & $\begin{array}{l}\text { Sisihan } \\
\text { Piawai }\end{array}$ & $\begin{array}{l}\text { Perbezaan } \\
\text { Min }\end{array}$ & Nilai-t & df & $\mathbf{p}$ \\
\hline Markah Ujian Pra & & 6.935 & 3.151 & & & & \\
\hline $\begin{array}{l}\text { Markah Ujian } \\
\text { pasca }\end{array}$ & 31 & 8.806 & 2.773 & -1.870 & -4.040 & 30 & .000 \\
\hline
\end{tabular}

\section{Hipotesis $\mathrm{H}_{0}$ 3: Tidak terdapat perbezaan yang signifikan dalam skor min markah pencapaian ujian pasca antara kumpulan kawalan dengan kumpulan rawatan}

Jadual 9 menunjukkan statistik skor min markah pencapaian ujian pasca bagi kumpulan kawalan dan kumpulan rawatan.

Jadual 9: Statistik Skor Min Markah Pencapaian Ujian Pasca Kumpulan Kawalan dan Kumpulan Rawatan

\begin{tabular}{llrrll}
\hline & Kumpulan Murid & N & Min & $\begin{array}{c}\text { Sisihan } \\
\text { Piawai }\end{array}$ & $\begin{array}{l}\text { Kesalahan } \\
\text { Min } \\
\text { Standard }\end{array}$ \\
\hline Markah Ujian & Kumpulan Kawalan 34 & 35.235 & 18.171 & 3.116 \\
Pasca & Kumpulan Rawatan 31 & 51.096 & 17.242 & 3.096 \\
\hline
\end{tabular}

Berdasarkan jadual 10, ujian Levene bagi kesamaan varians (Levene's test for equality of variances) yang tidak signifikan $(\mathrm{p}=.784>.05)$ menunjukkan bahawa kedua-dua kumpulan kawalan dan kumpulan rawatan mempunyai varians yang sama. Ini bermakna hipotesis nol yang menyatakan bahawa varians bagi kumpulan kawalan adalah sama dengan varians bagi kumpulan rawatan adalah gagal ditolak. Dengan itu, keputusan ujian-t bagi perbandingan min bagi dua kumpulan sampel tak bersandaran yang mempunyai varians yang sama adalah diambilkira (equal variances assumed). Memandangkan nilai kebarangkalian yang diperoleh (.001) adalah kurang daripada tahap kesignifikanan yang ditentukan (.05), maka hipotesis nol ditolak. Terdapat perbezaan yang signifikan 
dalam skor min markah pencapaian ujian pasca bagi kumpulan kawalan $(\min =35.235)$ dengan skor min markah pencapaian ujian pasca kumpulan rawatan $(\min =51.096)$ bagi topik pecahan. Kumpulan rawatan memperoleh skor min markah pencapaian ujian pasca yang lebih tinggi berbanding kumpulan kawalan.

Jadual 10: Statistik Ujian-t Kumpulan Kawalan dan Kumpulan Rawatan dalam Ujian Pasca

\begin{tabular}{|c|c|c|c|c|c|c|c|c|c|c|}
\hline & & $\begin{array}{r}\text { Levene's } \\
\text { Equali } \\
\text { Varia }\end{array}$ & $\begin{array}{l}\text { est for } \\
\text { y of } \\
\text { ces }\end{array}$ & & & t-tes & for Equality & of Means & & \\
\hline & & & & & & Sig. (2- & Mean & Std. Error & $\begin{array}{r}95 \% \text { Con } \\
\text { Interval } \\
\text { Differ }\end{array}$ & $\begin{array}{l}\text { ence } \\
\text { the } \\
\text { e }\end{array}$ \\
\hline & & $\mathrm{F}$ & Sig. & $\mathrm{t}$ & df & tailed) & Difference & Difference & Lower & Upper \\
\hline $\begin{array}{l}\text { Markah } \\
\text { Ujian }\end{array}$ & $\begin{array}{l}\text { Equal } \\
\text { variances }\end{array}$ & .076 & .784 & -3.601 & 63 & .001 & -15.861 & 4.404 & -24.662 & -7.061 \\
\hline Pasca & $\begin{array}{l}\text { assumed } \\
\text { Equal } \\
\text { variances not } \\
\text { assumed }\end{array}$ & & & -3.610 & 62.892 & .001 & -15.861 & 4.393 & -24.644 & -7.082 \\
\hline
\end{tabular}

\section{Perbincangan}

Dapatan kajian menunjukkan bahawa penggunaan Minecraft dalam pembelajaran berasaskan permainan digital telah membantu meningkatkan pencapaian murid berbanding penggunaan kaedah konvensional. Perbezaan ini menunjukkan bahawa penggunaan Minecraft telah memberi impak yang positif ke atas pencapaian murid. Minecraft menyediakan peluang kepada murid untuk melakukan manipulasi secara interaktif ke atas blok 3D dalam aktiviti-aktiviti yang melibatkan penyelesaian masalah pecahan dan dalam masa yang sama memberi hiburan serta menggalakkan keterlibatan aktif murid dalam proses pembelajaran. Elemen hiburan yang terdapat pada Minecraft telah menjadikan pembelajaran lebih menyeronokkan dan ini telah menarik perhatian murid terhadap pembelajaran sekali gus menyebabkan murid bermotivasi untuk mengikuti PdPc yang disampaikan guru selaras dengan kajian Hwang et. al., (2015), Yang (2015) dan Wang et. al., 2011).

Sebagai sebuah teknologi yang mempunyai ciri paparan grafik, Minecraft yang digunakan dalam kaedah pembelajaran berasaskan permainan digital telah membantu dalam meningkatkan pemahaman dan penguasaan konseptual pecahan di kalangan murid yang kemudiannya dapat diaplikasi semasa melakukan penyelesaian masalah pecahan. Ini adalah kerana melalui kajian yang dijalankan, didapati bahawa penggunaan Minecraft telah membantu murid untuk memvisualisasi konsep pecahan yang abstrak dengan lebih baik dan berkesan. Keupayaan murid untuk memvisualisasi konsep pecahan yang abstrak dengan lebih baik, mudah dan berkesan adalah kerana Minecraft membolehkan murid melakukan aktiviti yang melibatkan manipulasi ke atas blok 3D bagi membentuk model pecahan. Ini adalah sejajar dengan dapatan kajian oleh Kim dan Park (2018) yang mendapati bahawa pelaksanaan aktiviti matematik yang melibatkan Minecraft telah meningkatkan keberkesanan PdPc matematik dengan membantu murid untuk memvisualisasi konsep matematik dalam persekitaran maya dengan lebih baik dan berkesan. Murid boleh menyusun, mengalih, memindah, memusnah serta mengubah suai blok 3D di dalam Minecraft bagi membentuk nilai pecahan dan kemudiannya melaksanakan penyelesaian masalah pecahan melalui manipulasi ke atas blok 3D tersebut. Piaget (1965) turut menyatakan bahawa murid lazimnya akan mengalami kesukaran untuk memahami dan mempelajari konsep matematik yang abstrak apabila ditunjukkan sama ada dalam bentuk perkataan atau simbol melalui penjelasan secara langsung (direct explanation). Ini adalah kerana murid belum mencapai kematangan kognitif yang diperlukan untuk memahami konsep matematik yang abstrak tersebut. Dengan itu, beliau berpendapat bahawa murid berkemampuan untuk mempelajari konsep matematik yang abstrak dengan lebih baik dan berkesan hasil daripada pengalaman mereka berinteraksi dengan atau memanipulasi objek serta bahan konkrit. Minecraft membolehkan murid untuk melihat secara visual serta berinteraksi dengan blok 3D tersebut semasa pelaksanaan aktiviti penyelesaian masalah 
pecahan. Keupayaan murid untuk memvisualisasikan konsep pecahan yang abstrak dengan baik akan membantu dalam membentuk pemahaman konseptual pecahan yang kukuh (Abdul Halim et. al., 2015; Özkan et. al., 2018). Aktiviti manipulasi secara hands-on dalam persekitaran maya yang dilakukan ke atas blok 3D dalam Minecraft membantu mewujudkan hubungan di antara aktiviti manipulasi tersebut dengan konsep matematik yang abstrak kerana dengan berinteraksi dengan blok 3D melalui aktiviti manipulasi, kemahiran matematik murid akan dapat dipertingkatkan dan ini sekali gus akan membantu murid untuk memahami konsep matematik yang abstrak kerana murid dapat memvisualisasikan konsep tersebut dengan baik dalam minda (Holmes, 2013; Kontaş, 2016). Aktiviti manipulasi tersebut membolehkan murid mengintegrasi pengetahuan dan mengaitkannya dengan pemikiran mereka bagi memahami konsep matematik secara lebih menyeluruh (Boggan et. al., 2010; Kelly, 2006) dan ini menyumbang kepada keupayaan murid untuk melakukan penyelesaian masalah pecahan dengan lebih baik sehingga membawa kepada peningkatan pencapaian dalam pecahan.

Kaedah pembelajaran berasaskan permainan digital menggunakan Minecraft juga turut menggalakkan penglibatan aktif murid dalam PdPc. Ini adalah kerana kaedah pembelajaran ini merupakan kaedah pembelajaran yang berpusatkan murid. Murid akan terlibat secara aktif dalam melaksanakan aktivitiaktiviti penyelesaian masalah yang terdapat dalam dunia maya Minecraft disebabkan permainan digital berupaya mencipta pengalaman pembelajaran yang interaktif dengan mengubah bahan pembelajaran yang tidak aktif kepada bahan pembelajaran di mana murid adalah pemain dan peserta aktif selaras dengan kajian oleh Sugar dan Takacs, (1999). Penglibatan aktif murid dalam PdPc kesan penggunaan kaedah pembelajaran berasaskan permainan digital juga disebabkan oleh sifat permainan digital yang menyediakan persekitaran responsif di mana murid segera mengetahui apa yang sedang mereka lakukan dan apa yang sedang berlaku di dalam permainan digital berkenaan (Cruickshank \& Telfer, 1980). Ini akan mengekalkan keterlibatan serta minat murid untuk mengikuti PdPc dan semakin murid melibatkan diri secara aktif dan menyeluruh dalam penyampaian pengajaran, semakin banyak kemahiran dan pengetahuan yang akan diperolehi oleh murid. Kemahiran dan pengetahuan yang diperolehi oleh murid tersebut akan membantu dalam menyelesaikan masalah berkaitan pecahan sekali gus meningkatkan pencapaian murid dalam topik berkenaan.

\section{Implikasi Kajian}

Kajian ini membuktikan bahawa penggunaan Minecraft dalam PdPc khususnya PdPc Matematik berpotensi menyumbang kepada penghasilan persekitaran pembelajaran maya yang berupaya membantu murid mempelajari dan mempunyai kefahaman konseptual pecahan yang baik. Di samping itu, implikasi kajian ini juga adalah pembelajaran berasaskan permainan digital mampu meningkatkan pencapaian murid dalam pecahan serta mengetengahkan keperluan golongan guru untuk mendapat bimbingan serta latihan berkenaan pelaksanaan kaedah pembelajaran berasaskan permainan digital terutama dari segi pengintegrasian permainan digital dalam sesi PdPc.

\section{Kesimpulan}

Kajian yang dijalankan ini telah menunjukkan bahawa pembelajaran pecahan menggunakan Minecraft mampu memberikan impak positif terhadap pencapaian murid dalam pecahan. Keupayaan murid untuk melakukan penyelesaian masalah pecahan dengan baik akan membantu mencapai aspirasi kurikulum Matematik di Malaysia serta meningkatkan lagi prestasi Malaysia dalam pentaksiran antarabangsa seperti TIMSS dan PISA. Dengan itu, golongan pendidik perlu mengambil inisiatif untuk menggunakan kaedah pembelajaran berasaskan permainan digital memandangkan kaedah pembelajaran ini berpotensi menyokong dan meningkatkan pembelajaran khususnya pencapaian akademik. 


\section{Rujukan}

Abdul Halim Abdullah, Nur Liyana Zainal Abidin \& Marlina Ali. (2015). Analysis of Students' Errors in Solving Higher Order Thinking Skills (HOTS) Problems for the Topic of Fraction. Asian Social Science, 11(21), $133-142$.

Alibali, M. W. \& Sidney, P. G. (2015). Variability in the natural number bias: Who, when, how, and why. Learning and Instruction, 37, 56 - 61.

All, A., Nunez Castellar, E. P. \& van Looy, J. (2014). Measuring effectiveness in digital game-based learning: A methodological review. International Journal of Serious Games 1, 3- 20.

All, A., Plovie, B., Nuñez Castellar, E. P. \& Van Looy, J. (2017). Pre-test influences on the effectiveness of digital-game based learning: A case study of a fire safety game. Computers \& Education, 114, $24-37$.

Al-Azawi, R., Al-Faliti, F. \& Al-Blushi, M. (2016). Educational Gamification Vs. Game Based Learning: A Comparative Study. International Journal of Innovation, Management and Technology, 7(4), 132 - 136.

Almeda, D., Cruz, E. \& Dy, A. (2013). Addressing students' misconceptions and developing their conceptual understanding and procedural skills on fractions using manipulative materials. Dibentangkan pada Research Congress DLSU. 7 - 9 March 2013, Manila.

Annetta, L. A., Cheng, M. \& Holmes, S. (2010). Assessing twenty-first century skills through a teacher created video game for high school biology students. Research in Science \& Technological Education, 28(2), $101-114$

Azurah Mohd Johar \& Effandi Zakaria. (2015). Analisis kesilapan bagi tajuk pecahan dalam kalangan murid tahun empat. Jurnal Pendidikan Matematik, 3(2), 1 - 17.

Bawa, P., Watson, S. L. \& Watson, W. (2018). Motivation is a game: Massively multiplayer online games as agents of motivation in higher education. Computers \& Education, 123, $174-194$.

Behnamnia, N., Amirrudin Kamsin \& Maizatul Akmar Ismail. (2020). The Landscape of Research on the Use of Digital Game-based Learning Apps to Nurture Creativity among Young Children: A Review. Thinking Skills and Creativity, 37, $1-12$

Bickham, D. S., Vandewater, E. A., Huston, A. C., Lee, J. H., Caplovitz, A. G. \& Wright, J. C. (2003). Predictors of children's electronic media use: An examination of three ethnic groups. Media Psychology, 2, 107-137.

Boggan, M., Harper, S. \& Whitmire, A. (2010). Using manipulatives to teach elementary mathematics. Journal of Instructional Pedagogies, 3, 1 - 6

Booth, J. L., Newton, K. J. \& Twiss-Garrity, L. K. (2014). The impact of fraction magnitude knowledge on algebra performance and learning. Journal of Experimental Child Psychology, 118, $110-118$.

Bos, B., Wilder, L., Cook, M. \& O’Donnell, R. (2014). Learning mathematics through Minecraft. Teaching Children Mathematics, 21(1), 56 - 59

Bottge, B. A., Ma, X., Gassaway, L., Butler, M. \& Toland, M. D. (2014). Detecting and correcting fractions computation error patterns. Exceptional Children 80(2), 237 - 255.

Boyle, E. A., Hainey, T., Connolly, T. M., Gray, G., Earp, J. \& Ott, M. (2016). An update to the systematic literature review of empirical evidence of the impacts and outcomes of computer games and serious games. Computers \& Education, 94, 178 - 192

Bruner, J. S. (1977). Process orientation. Dalam D. B. Aichele and R. E. Reys (Eds.), Readings in secondary school mathematics. $\left(2^{\text {nd }}\right.$ ed.) Boston, MA: Prindle, Weber $\&$ Schmidt.

Burke, K. (2000). Sixty percent of all Americans play video games, contributing to the fourth straight year of double- digit growth for the interactive entertainment industry. Dipetik dari http://www.isda.com/releases/4-21-2000.html pada 7 Febuari 2020

Chang, K. E., Wu, L. J., Weng, S. E., \& Sung, Y. T. (2012). Embedding game-based problem-solving phase into problem-posing system for mathematics learning. Computers \& Education, 58(2), 775786.

Chen, Y.-H, Lin, C.-P, Loi, C.-K. \& Chan, T.-W. (2012). A Collaborative Cross Number Puzzle Game to Enhance Elementary Students' Arithmetic Skills. Turkish Journal of Educational Technology, $11(2), 1-15$ 
Chen, Y.-C. (2017). Empirical Study on The Effect of Digital Game-Based Instruction on Students' LearningMotivation and Achievement. Eurasia Journal of Mathematics, Science \& Technology Education, 13(7), 3177 - 3187.

Connolly, T. M., Boyle, E. A., MacArthur, E., Hainey, T., and Boyle, J. M. (2012). A systematic literature review of empirical evidence on computer games and serious games. Computers Education. 59, 661-686.

Creswell, J. W. (2014). Research Design: Qualitative, Quantitative and Mixed Methods Approaches. ( $4^{\text {th }}$ ed.). California: Sage publications.

Cruickshank, D. R. \& Telfer, R. (1980). Classroom games and simulations. Theory into Practice, 19, $75-80$.

Dienes, Z. P. (1973). Mathematics through the senses, games, dance and art. Windsor, UK: The National Foundation for Educational Research Publishing Company Ltd.

DeWolf, M. \& Vosniadou, S. (2015). The representation of fraction magnitudes and the whole number bias reconsidered. Learning and Instruction, 37, 39 - 49.

Dhlamini, Z. B. \& Kibirige, I. (2014). Grade 9 learners' errors and misconceptions in addition of fractions. Mediterranean Journal of Social Sciences, 5(8), 236 - 244.

Donellan, J. (2019). 50 Best Open World Games You Should Play. Dipetik dari https://culturedvultures.com/best-open-world-games/2/ pada 10 Jun 2020.

Ekaputra, G., Lim, C. \& Eng, K. I. (2013). Minecraft: A Game as an education and scientific learning tool. Dalam The Information Systems International Conference. Pada 2 - 4 Disember 2013. Bali: Indonesia.

Entertainment Software Association, (2019). 2019 Essential Facts About the Computer and Video Game Industry. Dipetik dari https://www.theesa.com/wpcontent/uploads/2019/05/ESA Essential facts 2019.pdf pada 17 April 2020.

Gay, L. R. \& Airasian, P. W. (2011). Educational Research: Competencis for Analysis and Application. (Twelfth ed.). NY: Pearson Education, Inc. Hartshorn, R. \& Boren, S. 1990. Experiential learning of mathematics: Using manipulatives. ERIC Clearinghouse on Rural Education and Small Schools.

Holmes, A. B. (2013). Effects of Manipulative Use on PK-12 Mathematics Achievement: A MetaAnalysis. Society for Research on Educational Effectiveness. Poster presented at the meeting of Society for Research in Educational Effectiveness, Washington, DC.

Huizenga, J. C. (2017). Digital game-based learning in secondary education. Tesis PhD Amsterdam: University of Amsterdam.

Hwang, G.-J., Hung, C.-M. \& Chen, N.-S. (2014). Improving learning achievements motivations and problem-solving skills through a peer assessment-based game development approach, Educational Technology Research and Development, 62(2), 129 - 145

Hwang, G.-J., Chiu, L.-Y. \& Chen, C.-H. (2015). A contextual game-based learning approach to improving students' inquiry-based learning performance in social studies courses. Computers \& Education, 81,13 - 25

Iacovides, I., Aczel, J., Scanlon, E., Taylor, J. \& Woods, W. (2011). Motivation, Engagement and Learning through Digital Games. International Journal of Virtual and Personal Learning Environments, 2(2), 1 - 16

IDSA. (2003). Top ten industry facts. Interactive Digital Software Association. Dipetik dari http://www.idsa.com/pressroom main.html pada 6 Mac 2020.

Kao, G. Y. M., Chiang, C. H. \& Sun, C. T. (2017). Customizing scaffolds for game-based learning in physics: Impacts on knowledge acquisition and game design creativity. Computers \& Education, $113,294-312$.

Kelly, C. A. (2006). Using Manipulatives in Mathematical Problem Solving: A Performance Based Analysis. The Montana Mathematics Enthusiast, 3, 184 - 193

Kline, T. (2005). Psychological Testing: A practical approach to design \& evaluation. California: Sage Publication Ltd.

Kementerian Pendidikan Malaysia. (2014). Dokumen Standard Kurikulum dan Pentaksiran. Putrajaya: Bahagian Pembangunan Kurikulum.

Kementerian Pendidikan Malaysia. (2015). Kurikulum Standard Sekolah Rendah: Dokumen Standard Kurikulum dan Pentaksiran Matematik Tahun 1. Putrajaya: Bahagian Pembangunan Kurikulum. 
Kirriemuir, J. \& McFarlane, A. (2004). Report 8: Literature review in games and learning. NESTA Future lab series. Dipetik dari http://www.futurelab.org.uk/download/pdfs/research/lit_reviews/Games_Review1.pdf pada 8 Mei 2020.

Kim, B., Park, H. \& Baek, Y. (2009). Not just fun, but serious strategies: Using meta-cognitive strategies in game- based learning. Computers \& Education, 52(4), $800-810$.

Kim, Y. R. \& Park, M. S. (2018). Creating a Virtual World for Mathematics. Journal of Education and Training Studies, 6(12), $172-183$

Khairuddin Nisa, Che Zalina Zulkifli, Nor Azah Abdul Aziz \& Norhisham Mohamad Nordin. (2017). Reka Bentuk Gamifikasi Pembelajaran Geografi Berasaskan Permainan Geoplay. Geografi, 5(1), $46-51$.

Kontaş, H. (2016). The Effect of Manipulatives on Mathematics Achievement and Attitudes of Secondary School Students. Journal of Education and Learning, 5(3), 10 - 20

Ku, O., Chen, S.-Y., Wu, D.-H., Lao, A.-C.-C. \& Chan, T.-W. (2014). The Effects of Game-Based Learning on Mathematical Confidence and Performance: High Ability vs. Low Ability. Educational Technology \& Society, 17(3), $65-78$.

Lamon, S. J. (2008). Teaching Fractions and Ratios for Understanding: Essential Content Knowledge and Instructional Strategies for Teachers. ( $2^{\text {nd }}$ ed.). New Jersey: Lawrence Erlbaum Associates.

Lane, H. C., Yi, S., Guerrero, B. \& Comins. (2017). Minecraft as a sandbox for STEM interest development: Preliminary results. Dalam Proceedings of the 25th International Conference on Computers in Education. Pada $4-8$ Disember 2017. Rydges Latimer Hotel, Christchurch: New Zealand.

Li, M.-C., and Tsai, C.-C. (2013). Game-based learning in science education: a review of relevant research. Journal of Science Education and Technology, 22, 877 - 898.

Li, H. C. (2014). A comparative analysis of British and Taiwanese students' conceptual and procedural knowledge of fraction addition. International Journal of Mathematical Education in Science and Technology 45(7), 968 - 979.

Loong, Y. (2014). Fostering mathematical understanding through physical and virtual manipulatives. The Australian Mathematics Teacher, 70(4), 3 - 10.

Malaysian Investment Development Industry. (2020). The Gaming Industry: A New Game of Growth. Dipetik dari https://www.mida.gov.my/home/-the-gaming-industry:-a-new-game-of-growth/posts/ pada 13 Mei 2020.

Meluso, A., Zheng, M., Spires, H. A., \& Lester, J. (2012). Enhancing 5th graders' science content knowledge and self-efficacy through game-based learning. Computers \& Education, 59(2), 497504.

McLaren, B. M., Adams, D. M., Mayer, R. E., and Forlizzi, J. (2017). A computer-based game that promotes mathematics learning more than a conventional approach. International Journal of Game Based Learning, 7, 36 - 56.

Mojang. (2015a). Minecraft. Dimuat turun dari https://minecraft.net/ pada 21 Mei 2019.

Mullis, I. V. S., Martin, M. O., Foy, P. \& Hooper, M. (2016). TIMSS 2015 International Results in Mathematics. Chestnut Hill, MA: Boston College

Ndalichako, J. (2013). Analysis of Pupils' Difficulties in Solving Questions Related to Fractions: The Case of Primary School Leaving Examination in Tanzania. Creative Education, 4, 69-73.

Ni, Y. \& Zhou, Y.-D. (2005). Teaching and learning fraction and rational numbers: The origins and implications of whole number bias. Educational Psychologist, 40(1), 27 - 52.

Nebel, S., Schneider, S., \& Rey, G. D. (2016). Mining learning and crafting scientific experiments: A literature review on the use of Minecraft in education and research. Educational Technology \& Society, 19(2), $355-366$.

Noorbaizura Thambi \& Leong, K. E. (2013). Effect of students' achievement in fractions using GeoGebra. SAINSAB, 16, 97 -1 06.

Nor Aishah Ahad, T., Sin Yin, Abdul Rahman Othman \& Che Rohani Yaacob. (2011). Sensitivity of normality tests to non-normal data. Sains Malaysiana, 40(6), $637-641$

Özkan, A., Arikan, E. E. \& Özkan, E. M. (2018). A Study on the Visualization Skills of 6th Grade Students. Universal Journal of Educational Research, 6(2), 354 - 359

OECD. (2013). PISA 2012 Results: What Students Know and Can Do - Students Performance in Mathematics, Reading and Science (Volume 1). OECD Publishing. 
Piaget, J. (1965). The child's conception of number. New York: W. W. Norton \& Company.

Prensky, M. (2001). Digital game-based learning. New York, NY: McGraw-Hill.

Ritterfeld, U., \& Weber, R. (2006). Video Games for Entertainment and Education. Dalam P. Vorderer \& J. Bryant (Eds.), Playing video games: Motives, responses, consequences, 399-413. Lawrence Erlbaum Associates Publishers.

Rodrigues, J., Dyson, N. I., Hansen, N. \& Jordan, N. C. (2017). Preparing for algebra by building fraction sense. Teaching Exceptional Children, 49, 134 - 141

Siegler, R. S., \& Pyke, A. A. 2(013). Developmental and individual differences in understanding of fractions. Developmental Psychology. Advance online publication.

Siew Nyet Moi@Sopiah Abdullah, Jolly Geofrey \& Lee, B. N. (2016). Students' Algebraic thinking and Attitudes towards Algebra: The Effects of Game-Based Learning Using DragonBox 12+ App. Electronic Journal of Mathematics \& Technology, 10(1), 1-17

Simon, M. A., Placa, N., Avitzur, A. \& Kara, M. (2018). Promoting a concept of fraction-as- measure: A study of the Learning Through Activity research program, Journal of Mathematical Behavior, $52,122-133$

Short, D. (2012). Teaching scientific concepts using a virtual world - Minecraft. Teaching Science, $58(3), 55-58$.

Stafylidou, S. \& Vosniadou, S. (2004). The development of students' understanding of the numerical value of fractions. Learning and Instruction, 14, $503-518$.

Sugar, S. \& Takacs, G. (1999). Games that teach teams: Tale of the RAT. The Journal for Quality and Participation, 22, $54-55$.

Van de Walle, J.A., Karp, K.S. \& Bay-Williams, J. M. (2019). Elementary and middle school mathematics teaching developmentally (Tenth Edition), USA: Pearson Publications.

Wang, Y., Liu, X., Lin, X. \& Xiang, G. (2011). An Evaluation Framework for Game-Based Learning. Dibentang di The $15^{\text {th }}$ Global Chinese Conference on Computers in Education. Pada 29 hingga 31 Mei 2011. Hangzhou, China.

Westera, W. (2015). Games are motivating, aren't they? Disputing the arguments for digital gamebased learning. Internationl Journal of Serious Games, 2, 4-1 7

Wiggins, B. E. (2016). An Overview and Study on the Use of Games, Simulations, and Gamification in Higher Education. International Journal of Game-Based Learning, 6(1), 18-29.

Wijaya, A. (2017). The relationships between Indonesian fourth graders' difficulties in fractions and the opportunity to learn fractions: A snapshot of TIMSS results. International Journal of Instruction, 10(4), 221-236

Wijman, T. (2020). The World's 2.7 Billion Gamers Will Spend \$159.3 Billion on Games in 2020; The Market Will Surpass $\$ 200$ Billion by 2023. Dipetik dari https://newzoo.com/insights/articles/newzoo-games-market-numbers-revenues-and-audience2020-2023/ pada 8 Jun 2020.

Williams, M., Curtis, M. J. \& Mullane, K. (2017). Research in the biomedical sciences: Transparent and reproducible. Indian Journal of Medical Research. ( $1^{\text {st }}$ ed.). Academic Press, London.

Wong, W. S. \& Kamisah Osman. (2018). Pembelajaran Berasaskan Permainan dalam Pendidikan STEM dan Penguasaaan Kemahiran Abad ke-21. Politeknik \& Kolej Komuniti Journal of Social Sciences and Humanities, 3(1), $121-135$.

Yang, Y. T. C. (2015). Virtual CEOs: A blended approach to digital gaming for enhancing higherorder hinking and academic achievement among vocational high school students Computers \& Education, 81, $281-295$

Yeh, Y., Hung, H. \& Hsu, Y. (2017). Digital Game-Based Learning for Improving Students'AcademicAchievement, Learning Motivation, and Willingness to Communicate in an English Course. Dibentangkan di 6th International Congress on Advanced Applied Informatics. Pada 9 - 13 Julai 2017. Hamamatsu, Jepun.

Zakiah Salleh, Norhapidah Mohd Saad, Mohamad Nizam Arshad, Hazaka Yunus \& Effandi Zakaria. (2013). Analisis jenis kesilapan dalam operasi penambahan dan penolakan pecahan. Jurnal Pendidikan Matematik, 1(1), 1 - 10 